\title{
TRATADOS INTERNACIONAIS EM MATÉRIA TRIBUTÁRIA E SUA RELAÇÃO COM O DIREITO INTERNO NO BRASIL
}

\author{
Gustavo Mathias Alves Pinto
}

THE IMPACT OF THE INTERNATIONAL TREATIES ON TAX LAW ON THE BRAZILIAN LAW

\section{RESUMO}

ESTE ARTIGO TEM COMO OBJETIVO APRESENTAR OS PRINCIPAIS ASPECTOS A RESPEITO DO TRATAMENTO OFERECIDO AOS TRATADOS INTERNACIONAIS EM MATÉRIA TRIBUTÁRIA NO ORDENAMENTO JURÍDICO BRASILEIRO. PARA TAL, O ARTIGO ANALISA AS CARACTERÍSTICAS DESSES TRATADOS ENQUANTO FONTE DE DIREITO INTERNACIONAL, SEU POSICIONAMENTO HIERÁRQUICO PERANTE A CONSTITUIÇÃO FEDERAL E LEGISLAÇÄO INFRACONSTITUCIONAL, BEM COMO A JURISPRUDÊNCIA MAIS RELEVANTE A RESPEITO DA MATÉRIA. AO FINAL, PRETENDE-SE DEMONSTRAR QUE, NOS CASOS ESPECIFICOS SOBRE OS QUAIS TAIS INSTRUMENTOS VERSAREM, ESTES PREVALECEM SOBRE O ORDENAMENTO INTERNO EM RAZÃO DO PRINCÍPIO DA AUTOLIMITAÇÃO DA SOBERANIA NO TOCANTE À IMPOSIÇÃO TRIBUTÁRIA.

\section{PALAVRAS-CHAVE}

SOBERANIA, TRATADOS INTERNACIONAIS, MATÉRIA TRIBUTÁRIA, ACORDOS DE BITRIBUTAÇÃO, CONFLITO DE LEIS

\begin{abstract}
THE FOLLOWING ARTICLE PRESENTS THE MAIN ASPECTS OF THE INTERACTION BETWEEN TAX TREATIES AND NATIONAL LAW WITHIN THE BRAZILIAN LEGAL SYSTEM. THE ARTICLE ANALYSES THE CHARACTERISTICS OF SUCH TREATIES AS SOURCES OF INTERNATIONAL LAW, THEIR HIERARCHY BEFORE THE CONSTITUTION AND LEGISLATION, AS WELL AS THE RELEVANT JURISPRUDENCE ON THE SUBJECT. THE ARTICLE AIMS AT DEMONSTRATING THAT, REGARDING THE SPECIFIC SITUATIONS ADDRESSED IN ITS BODY, THE TAX TREATY TAKES PRECEDENCE OVER THE NATIONAL LAW, BASED ON THE PRINCIPLE OF SELFLIMITATION OF TAXATION POWER.

\section{KEYWORDS}

SOVEREIGNTY, INTERNATIONAL TREATIES, TAX LAW, DOUBLE TAXATION AGREEMENTS, CONFLICT OF LAWS

\section{Soberania E SUAS Feições}

Foi o jurista francês Jean Bodin quem pela primeira vez empregou o termo soberania para identificar novos Estados independentes que se formaram na Europa a partir do século XIII. À ocasião, definiu-a como o poder absoluto e perpétuo de uma república, vinculado, todavia, ao direito natural e ao direito das gentes (GRUPENMACHER, 1999, p. 11). Essa noção foi posteriormente desenvolvida por Hegel, que afirmava não haver ordenamento jurídico superior apto a limitar o ordenamento jurídico estatal. Para Hegel, o Estado é a encarnação do poder absoluto, 
tendo a prerrogativa de concluir tratados internacionais, mas permanecendo acima deles diante de sua vontade incontrastável.

Observa-se que há mais de um conceito de soberania. Na verdade, há vários, e até mesmo Burdeau, ao cuidar da matéria, reconheceu não ser possível esgotá-los todos (BURDEAU, 1982, p. 51-52, apud TÔRRES, 2001, p. 62). Pode-se dizer, no entanto, que, buscando um espaço de redução lógica comum, tem-se na soberania uma expectativa de neutralização de qualquer espécie de subordinação da autoridade estatal e uma qualidade do poder estatal (TÔRRES, 2001, p. 62). Na concepção clássica adotada por Hans Kelsen, para orientar sua defesa do monismo internacional, a soberania também é fenômeno vinculado à noção de poder reconhecido internacionalmente.

Xavier (1993, p. 13) aponta uma divisão entre soberania pessoal e territorial. A primeira seria o poder de legislar sobre as pessoas que integram um determinado Estado pela nacionalidade, independentemente do local onde se encontram. Já a soberania territorial é o poder do Estado de legislar relativamente a pessoas, coisas ou fatos que se localizam no seu território.

Schoueri (2003, p. 21) chama a atenção a outro aspecto da soberania. Segundo o autor, ela se apresenta de maneira dupla, dividindo-se em soberania interna e soberania externa. A soberania interna poderia ser explicada como poder de o Estado estruturar livremente sua ordem jurídica, poder este necessariamente submetido ao direito. Não é essa a noção que mais nos interessa neste estudo, uma vez que, enquanto reduzida ao seu aspecto interno, a soberania não produz efeitos que afetam o direito tributário internacional, cujo interesse está naquelas relações em que a pretensão estatal, especialmente a tributária, estende-se além fronteiras. Como exemplo de uma situação em que a pretensão estatal estende-se além das fronteiras, Schoueri cita o art. 43, § 2. ${ }^{\circ}$, da Lei Complementar $n^{\circ}$ 104/2001, que permite a possibilidade de o imposto de renda atingir receita ou rendimento oriundos do exterior (SCHOUERI, 2003, p. 21). É justamente nesse ponto que reside a importância do aspecto externo da soberania. À medida que os Estados estendem suas pretensões tributárias para alcançar situações ocorridas além de suas fronteiras, torna-se mais freqüente a cumulação de pretensões, gerando o fenômeno da bitributação internacional, que, conquanto não seja algo ilícito, é vista como algo repudiável por questões de ordem econômica, principalmente por apresentar-se como obstáculo intransponível ao comércio exterior, além de implicar uma injusta distribuição de carga tributária (GRUPENMACHER, 1999, p. 92). Por isso, Hector Villegas afirmou que, modernamente, tem-se observado que a bitributação internacional apresenta-se como um obstáculo ao desenvolvimento econômico e social dos países, principalmente dos pouco desenvolvidos (VILLEGAS, 1994, p. p. 483-484, apud GRUPENMACHER, 1999, p. 93). 
Em função desse senso comum quanto aos efeitos perversos desse tipo de situação podemos encontrar na atualidade limitações quanto à soberania. Nesse sentido, por exemplo, é que Tôrres afirma que é lícita a atividade legislativa do Estado, desde que mediante a utilização de critérios de conexão que exprimam um contato efetivo entre o fato evento com elementos de estraneidade e o Estado, que tem a pretensão de discipliná-lo fiscalmente (TÔRRES, 2001, p. 69).

Da mesma forma, Xavier (1993, p. 13) afirma que o direito internacional público reconhece automaticamente aos Estados o poder de tributar limites em que ele se estende, mas recusa-lhes tal poder na medida em que esses limites forem ultrapassados, de tal modo que, se um Estado tributar estrangeiros em função de situações que não tenham qualquer conexão com o seu território, estará violando o direito internacional.

No entanto, é importante salientar que tais limitações não devem ser vistas como afronta à soberania, mas como preservação desta, por meio da submissão à lei, uma vez que o Estado, ao autolimitar-se, determina sua vontade por ele próprio, permanecendo soberano.

Assim, observa-se que, quando analisamos a soberania na sua faceta externa, constatamos que, na atualidade, ela não é mais considerada o poder absoluto dos Estados, tal como o era antigamente. Em face de um contexto internacional atual que impõe cooperação cada vez maior entre países, é necessário que os Estados limitem parte de sua soberania. Trata-se do fenômeno a que Jhering se referiu por regra da autolimitação (SCHOUERI, 2003, p. 21). Essa solidariedade de interesses entre as nações é bem refletida no caso italiano, em que o país fez constar no art. 11 de sua Carta Magna disposição segundo a qual o país consente, nas condições de paridade com outros Estados, as limitações à soberania necessárias a uma ordem internacional capaz de assegurar a paz e a justiça entre as nações.

Dessa forma, como Xavier bem apontou, é no âmbito do direito internacional que encontramos limites à soberania externa. Cumpre-nos, portanto, encontrar suas fontes para que se possa prosseguir neste estudo.

\section{FONTES DO DIREITO INTERNACIONAL - O TRATADO INTERNACIONAL}

Podemos encontrar as fontes do direito internacional no art. 38 do Estatuto da Corte Internacional de Justiça. Segundo o dispositivo, são fontes de direito internacional o direito consuetudinário, os princípios de direito geralmente reconhecidos pelas nações civilizadas e os tratados internacionais.

Soares (2002, p. 55) afirma que o rol de fontes apresentado pelo art. 38 do Estatuto da Corte Internacional de Justiça contém uma lacuna, pois deixou de mencionar as declarações unilaterais dos Estados com efeitos jurígenos no direito internacional e as decisões tomadas pelas organizações internacionais 
intergovernamentais. Segundo o autor, ambos os instrumentos já eram reconhecidos pela doutrina dominante à época da elaboração do Estatuto como fontes de direito internacional.

Independentemente do número exato de fontes existentes, importa-nos constatar que os tratados internacionais são reconhecidos como uma fonte de direito internacional. Assim, considerando que o objeto principal desta análise são tratados internacionais em matéria tributária, cabe-nos fazer uma análise mais detalhada a respeito destes e de sua abrangência.

Para fins da Convenção de Viena sobre Direito dos Tratados (1969), ${ }^{1}$ tratado significa "um acordo internacional celebrado entre Estados em forma escrita e regido pelo direito internacional, que conste ou de um instrumento único ou de dois ou mais instrumentos conexos, qualquer que seja sua denominação específica”. ${ }^{2}$

A primeira inferência que pode ser realizada sobre a definição constante da Convenção é que, segundo esta, o tratado visa regular somente relações mútuas entre Estados, não envolvendo outros entes de direito internacional. Tal limitação correspondeu à circunstância de que as regras da Convenção foram fixadas pelos Estados negociadores para regularem tão apenas as suas relações mútuas. Inexistiu, assim, qualquer interesse na regulação de tratados entre Estados e outros entes de direito internacional, ou entre estes apenas, embora a existência de tratados celebrados por outros sujeitos de direito internacional seja expressamente reconhecida no art. 3. ${ }^{\circ}$ da Convenção (BAHIA, 2000, p. 1).

Também critica-se o fato de a Convenção ter inserido na definição do termo a expressão "que conste, ou de instrumento único ou de dois ou mais instrumentos conexos”. Com efeito, a referida expressão não é essencial ao conceito, pois a uniinstrumentalidade ou pluriinstrumentalidade servem apenas para distinguir os tratados, e não defini-los (BAHIA, 2000, p. 2).

Em razão dessas alegadas insuficiências do conceito exposto na Convenção de Viena, doutrinadores cuidaram de tecer outras definições sobre o tratado que, a seu ver, são mais fiéis à realidade do instituto.

Assim, por exemplo, segundo Rezek, o tratado é "todo acordo formal concluído entre sujeitos de direito internacional público, e destinado a produzir efeitos jurídicos" (REZEK, 1995, p. 14). Já segundo Hildebrando Accioly, o tratado é o "ato jurídico por meio do qual se manifesta o acordo de vontades entre duas ou mais pessoas internacionais" (ACCIOLY, 1956, p. 20).

Nas doutrinas brasileira e estrangeira, são diversas as definições de tratados. Não cabe aqui destrinchar cada uma delas, uma vez que fugiria ao escopo do trabalho. Considera-se mais proveitoso enunciar o núcleo comum que pode ser encontrado nas definições expostas pelos doutrinadores.

Segundo esse núcleo comum, o tratado internacional pode ser definido como um acordo de vontades entre pessoas de direito internacional, regido pelo direito das 
gentes. Os três elementos mais importantes dessa definição são: (i) o consentimento, do que se percebe que atos unilaterais não podem gerar tratados; (ii) a personalidade internacional dos contratantes; e iii) a regência pelo direito internacional, demonstrando que o controle de consentimento (aí incluindo-se forma e objeto) e dos efeitos jurídicos do acordo não fica a cargo do direito interno das partes no tratado (BAHIA, 2000, p. 2-3).

Neste ponto, cabe fazer uma ressalva. Há diversas classificações difundidas acerca dos tratados internacionais. Alguns autores defendem que é melhor usar o termo “convenção" para tratados do tipo normativo, enquanto outros autores defendem aplicações específicas para acordo, ajuste ou convênio. Para Saulo José Casali Bahia, tratado seria gênero, do qual todas essas espécies de atos internacionais seriam espécie (BAHIA, 2000, p. 3-6). Já Bernardo Ribeiro de Moraes defende que tratado e convenção são sinônimos, ambos representando o ato jurídico firmado por dois ou mais Estados, mediante seus respectivos órgãos competentes, com o objetivo de estabelecer normas comuns de direito internacional.

Em razão dessas classificações, surgem, por exemplo, críticas ao fato de o art. 98 do Código Tributário Nacional ter disposto em sua redação que: "Os tratados e as convenções internacionais revogam ou modificam [...]”. Segundo autores que consideram o tratado como gênero, do qual convenção seria espécie, a expressão utilizada no artigo seria redundante. A mesma crítica se aplicaria ao art. 84, VIII, da Constituição Federal, em que está prevista competência privativa do presidente para celebrar tratados, convenções e atos internacionais.

Conquanto concordemos com o posicionamento de Bahia sobre a questão, a discussão é infrutífera para os fins pretendidos neste estudo. Dessa forma, utilizaremos o vocábulo tratado como termo genérico a designar um acordo de vontades entre pessoas de direito internacional e regido pelo direito das gentes.

No tocante às classificações atribuídas aos tratados internacionais, interessamnos apenas duas. A primeira é a distinção entre tratados em matéria tributária e os que a afetam , examinada no tópico a seguir. A segunda é a distinção entre tratadosnormativos e tratados-contrato, objeto de análise detida mais adiante.

\section{I TRATADOS INTERNACIONAIS QUE AFETAM MATÉRIA TRIBUTÁRIA}

Xavier (1993, p. 87) afirma que há convenções internacionais que, embora versando essencialmente sobre outra matéria, contemplam, acidental ou acessoriamente, disposições tributárias. O autor cita como exemplos os acordos visando à formação de zonas aduaneiras, ou de livre comércio, bem como a outros que tratam de assuntos como imunidades diplomáticas e consulares.

Schoueri (2003, p. 23) também faz distinção entre os tratados internacionais que afetam matéria tributária e os tratados internacionais em matéria tributária. Quanto aos primeiros, cita como exemplo o Acordo Geral de Tarifas e Comércio (Gatt), que 
abole discriminação nas relações comerciais mediante a extensão generalizada da cláusula da nação mais favorecida. Trata-se de fato intrinsecamente ligado ao fenômeno de integração econômica que pode ser observado na atualidade. Além do Gatt, outros acordos comerciais que afetam matéria tributária podem ser citados, como o Tratado de Roma, o Mercosul e o Nafta.

Assim, é importante apenas demonstrar que pode haver tratados que não tenham por objeto matéria tributária, mas que venham a afetá-la. No entanto, a heterogeneidade desses tratados dificulta um tratamento dogmático unitário à matéria e, além disso, não se enquadram na categoria que aqui nos interessa.

\subsection{TRATADOS INTERNACIONAIS EM MATÉRIA TRIBUTÁRIA}

Os tratados internacionais podem versar sobre as mais diversas matérias, e, entre elas, obviamente está a matéria tributária.

Com freqüência quase absoluta, os tratados em matéria tributária dispõem sobre acordos de bitributação. A bitributação, conforme visto, é a coincidência de pretensão tributária de natureza semelhante de mais de um Estado sobre um mesmo contribuinte, em virtude da mesma circunstância e relativa ao mesmo período. Os acordos de bitributação são os instrumentos de que se valem os Estados para evitar ou mitigar os efeitos da bitributação por meio de concessões mútuas.

Schoueri (2003, p. 27) oferece um bom panorama sobre a evolução dos acordos de bitributação. Aponta o autor que, já no final do século XIX, os Estados passaram a adotar acordos bilaterais para evitar a bitributação da renda. No começo, o fenômeno era observado apenas entre Estados limítrofes, no entanto, com o decorrer do tempo, e principalmente após o final da Primeira Guerra Mundial, observou-se a construção de uma rede de acordos na Europa Central, fenômeno que acabou se alastrando pelo resto do mundo com o fim da Segunda Guerra Mundial.

Muito dessa evolução quanto aos acordos de bitributação pode ser atribuída ao trabalho da Sociedade das Nações, que elaborou um modelo uniforme de acordo de bitributação a ser seguido pelos países. Em 1921, quatro especialistas em finanças públicas foram encarregados pelo Comitê Financeiro da Sociedade das Nações de apresentar um relatório sobre os problemas econômicos decorrentes da bitributação e quais seriam as possíveis soluções para o problema.

Entre 1926 e 1927, com o auxílio de especialistas europeus e norte-americanos, o Comitê elaborou quatro modelos de acordos, que tratavam, além dos impostos diretos, do imposto de sucessões, da assistência administrativa e da assistência judiciária. Tais modelos foram aprovados, em 1928, por representantes de 28 Estados. Em 1940, após diversas reuniões do Comitê Permanente de Assuntos Fiscais, foi sugerida a revisão dos modelos de 1928, realizada em 1943, quando consagraram-se os interesses dos países menos desenvolvidos, com aceitação da tributação segundo o princípio da fonte. Essa situação não tardou a mudar, uma vez que, encerrado o conflito mundial, 
quando os países desenvolvidos puderam voltar a centrar suas atenções na discussão, surgiu um novo modelo que privilegiava a tributação na residência.

A Organização das Nações Unidas procurou retomar os trabalhos da Sociedade das Nações, tendo sido propostos o exame e a revisão dos modelos na primeira reunião do Comissão de Finanças Públicas. Não obstante, os trabalhos da organização nessa época restaram infrutíferos. Somente em 1967, por influência dos trabalhos da Organização de Cooperação e Desenvolvimento Econômicos, esta retomaria seus trabalhos para a criação de um modelo de acordo de bitributação.

Em 1956, foi instituído um Comitê Fiscal com a tarefa de apresentar um novo modelo de acordo de bitributação pela Organização Européia de Cooperação Econômica, que posteriormente (1961) passaria a se chamar Organização de Cooperação e Desenvolvimento Econômicos (OCDE). O Comitê Fiscal concluiu seus trabalhos em 1963, apresentando um modelo de acordo de bitributação, em que, à semelhança do modelo elaborado no pós-guerra pela Sociedade das Nações, contemplava-se a tributação na residência. O Comitê para Assuntos Fiscais existente na atualidade é a evolução deste Comitê Fiscal, e ainda hoje continua a trabalhar na convenção-modelo e em seus comentários.

\section{RELAÇÃO COM O DIREITO INTERNO}

Tecidas essas considerações a respeito dos tratados em matéria tributária e compreendida a importância deles no contexto internacional atual, cumpre-nos analisar agora sua relação com o direito interno. Nesse aspecto, o primeiro ponto a ser discutido é a questão da sua prevalência sobre os sistemas positivos de cada país.

Discute a doutrina, já de longa data, quanto à relação entre o direito interno e o direito internacional, existir uma dicotomia identificada como monismo e dualismo das ordens jurídicas. Embora não reputemos a importância que muitos da doutrina atribuem à questão, posição compartilhada com Tôrres (2001, p. 553) é necessário conhecer tais correntes teóricas acerca da relação entre direito internacional e direito interno, uma vez que as conseqüências da opção por uma ou outra tese implicarão reconhecimento de efeitos específicos quanto à forma de admissão do direito internacional ao direito positivo de um Estado, bem como quanto ao modo de relacionamento entre tais normas, no tocante à hierarquia sistêmica das mesmas.

\section{I Monismo}

Com seu precursor em Kelsen, a corrente monista sustenta a existência de uma única ordem jurídica que engloba as ordens interna e a internacional. Segundo esta corrente, não são necessárias normas de fonte interna que reproduzam os mandamentos contidos nas regras constantes de um tratado internacional, uma vez que se trata do 
mesmo ordenamento. Assim, pode-se dizer que a essência do monismo repousa na plena integração do direito interno com o direito internacional.

Podemos encontrar três vertentes distintas na corrente monista: a primeira sustentando a primazia do direito interno; a segunda, a primazia do direito internacional; e a terceira vertente, conciliatória, que pode ser chamada de monismo moderado.

Com origem em Hegel, a vertente que defende a primazia do direito interno afirma ter o Estado soberania absoluta, não se sujeitando a qualquer outro sistema jurídico. Seus defensores negam o direito internacional em razão da soberania absoluta do Estado. De acordo com essa corrente, o direito internacional seria apenas um direito interno que os Estados aplicam na sua vida internacional. Assim, o direito estatal não passaria de um direito estatal externo. Essa corrente é duramente criticada por Charles Rousseau, que chama a atenção para o fato de o direito internacional ser composto também por princípios e normas consuetudinárias, não se limitando unicamente aos tratados.

A vertente que defende a primazia do direito internacional, cujo principal defensor durante muito tempo foi Kelsen (DOLINGER, 1996, p. 75), nega a existência de dois ordenamentos jurídicos autônomos e entende que só a ratificação dos tratados produz, concomitantemente, efeitos nos ordenamentos interno e internacional. Essa vertente baseia-se essencialmente no princípio pacta sunt servanda, segundo o qual os Estados não podem descumprir o que contrataram entre si.

Para Kelsen, segundo o direito internacional, o governo de um Estado é legítimo quando é efetivo e independente. Isto significa que, de acordo com o direito internacional, uma autoridade estabelecida de fato é o governo legítimo, sendo válida a ordem jurídica coercitiva estabelecida por este governo. Assim, as normas fundamentais dos diversos ordenamentos jurídicos nacionais são baseadas em uma norma geral do ordenamento jurídico internacional. Nesse sentido, conclui que a norma fundamental do ordenamento jurídico internacional é, também, a razão última da validade dos ordenamentos jurídicos nacionais. ${ }^{3}$

Essa corrente também é objeto de críticas, por simplesmente ignorar a existência de normas de direito interno que vão contra a ordem internacional e, mesmo assim, permanecem válidas no âmbito do Estado.

Dos atritos entre ambas as correntes acabou surgindo uma terceira corrente, conciliatória, qual seja, a do monismo moderado. Fundada por Alfred Verdross, defende a paridade hierárquica do direito internacional e do direito interno. De acordo com Jacob Dolinger, os seguidores dessa vertente postulam que os juízes nacionais devem aplicar tanto o direito nacional quanto o internacional, de acordo com a regra lex posterior derogat priori, aplicada pelas jurisprudências americana e brasileira (DOLINGER, 1996, p. 75). 


\subsection{Dualismo}

Liderada por Karl Heinrich Triepel, na Alemanha, e Dionísio Anzilotti, na Itália, a corrente dualista reconhece nos ordenamentos interno e internacional duas ordens distintas. Duas ordens que se ignoram e não se superpõem.

Segundo Triepel, a classificação das normas jurídicas deve ser feita a partir das relações sociais de que tratam, distinguindo-se aí diversos ramos diferentes (direito administrativo, penal etc.), ou a partir da vontade de que emanam. Considerando esses aspectos, direito interno e internacional seriam opostos nos dois sentidos supracitados.

$\mathrm{Na}$ corrente dualista, uma norma de direito internacional somente passa a vigorar na ordem interna se o mandamento nela contido for reproduzido por meio de uma norma do direito nacional, passando a ter fonte interna (teoria da transformação). Havia dissonâncias quanto a essa corrente, com autores que defendiam a possibilidade de uma norma de direito internacional passar a vigorar no direito interno por meio da teoria da adoção. Triepel era um defensor da primeira corrente, afirmando a necessidade de um ato legislativo de incorporação para que uma norma internacional pudesse ter aplicabilidade e eficácia no plano interno.

Charles Rousseau novamente critica o posicionamento dos dualistas, sustentando que a origem da norma do direito interno e do direito internacional público seria sempre a mesma, qual seja, o produto da vida social. Além disso, também chama a atenção para o fato de haver normas que versam sobre direito interno e internacional, como normas sobre competência para celebrar tratados.

Assim como o monismo, podemos encontrar duas vertentes distintas para o dualismo. Em primeiro lugar, tem-se o chamado dualismo extremado, que exige um ato de incorporação legislativa que transforme todas as normas de um tratado em direito nacional, ou seja, exige uma lei formal que reproduza o conteúdo do tratado.

Em segundo lugar, há o dualismo moderado, que defende uma divisão fundamental entre as ordens estatal e internacional, mas reconhece que relações Estado-indivíduo e indivíduo-indivíduo também são objeto de direito internacional. Segundo essa corrente, a incorporação prescindiria de lei, embora possuísse iter procedimental complexo, com aprovação congressual e promulgação executiva. ${ }^{4}$

Segundo Schoueri (2003, p. 30), não obstante as divergências teóricas iniciais, atualmente monistas e dualistas evoluíram para versões moderadas, sendo possível afirmar que, hoje, suas divergências repousam apenas sobre os princípios jusfilosóficos, não acarretando qualquer conseqüência na busca de soluções para questões concretas pontuais.

Nesse mesmo sentido, Charles Rousseau também qualifica a controvérsia doutrinária entre monismo e dualismo como discussion d'école. Realmente, há quem argumente que é mera questão de interpretação constitucional. Nos Estados Unidos, por exemplo, os tribunais americanos não recorreram às escolas dualista e monista para explicar a relação entre direito legal e convencional e a solução para 
suas antinomias. O problema foi resolvido contando unicamente com a cláusula da supremacia da Constituição. Naquele país, leis sancionadas e tratados celebrados sob a autoridade do representante para tal são declarados lei suprema da terra, e nenhuma autoridade soberana é dada a uns sobre os outros. A última vontade soberana é que vale.

\section{Sistemática da Constituição Federal}

Tecidas essas considerações a respeito do tratamento doutrinário à questão do relacionamento entre fontes internas e internacionais, pode-se passar à análise específica do caso brasileiro. Nesse sentido, faz-se mister examinar a forma como a Constituição Federal brasileira dispõe sobre os tratados e sua incorporação.

$\mathrm{O}$ art. 84, VIII, da Constituição Federal dispõe expressamente que compete privativamente ao Presidente da República celebrar tratados, convenções e atos internacionais, sujeitos a referendo do Congresso Nacional.

Dessa forma, quem pode celebrar tratados é apenas o Presidente da República. No entanto, cabe ressaltar que ele pode delegar essa função a um plenipotenciário, representante do Executivo, segundo o direito interno, investido de poder para expressar a vontade do representado, no caso, o Presidente da República. Excetuando alguns casos relativos a chefes de missões diplomáticas, os plenipotenciários carregam um documento denominado "carta de plenos poderes”, que os habilita a representar o Estado na negociação, adoção, autenticação ou mesmo expressão, em termos definitivos, do consentimento em obrigar-se por um tratado.

Uma vez celebrado o tratado, há duas possibilidades. Se este acarretar encargos ou compromissos gravosos ao patrimônio nacional, deve ser encaminhado ao Congresso para referendo. Trata-se de mandamento previsto no art. 49, I, da Constituição. Pode-se dizer que é uma tradição constitucional brasileira desde 1891, sendo a única exceção a Carta Magna de 1937. Se o tratado não acarretar encargos ou compromissos gravosos ao patrimônio nacional, não haverá necessidade de referendo, cabendo apenas a ratificação pelo Executivo posteriormente.

Salienta-se que o envio do tratado ao Congresso Nacional é um ato discricionário do Presidente. Se ele não quiser enviar, não é necessário; no entanto, tampouco poderá o tratado ser ratificado depois.

$\mathrm{Na}$ prática, as hipóteses de tratados que não incidem no art. 49, I, da Constituição, são muito escassas. Um possível exemplo de tratados que dispensariam a análise do Congresso são os acordos executivos. Trata-se dos acordos de caráter meramente administrativo, como acordos de cooperação para troca de informações, nos quais não se vislumbra nenhum encargo ou compromisso gravoso ao patrimônio nacional. No entanto, isso não é ponto pacífico na doutrina. Entre os 
autores que defendem a hipótese supracitada, podem-se citar Celso Albuquerque de Mello, Guido Soares e Vicente Marotta Rangel. Entre os contrários, podem-se mencionar Manoel Gonçalves Ferreira Filho, José Cretella Júnior e Oscar Dias Correa. (BAHIA, 2000, p. 50-55) Na prática, a questão perde relevância, uma vez que, na maioria dos casos, o Congresso encontra pretexto para invocar o art. 49, I. Além disso, no caso dos acordos de bitributação, estes invariavelmente implicam incidência do referido artigo.

De fato, o entendimento do Congresso quanto à incidência do art. 49, I, é tão abrangente, que abarca inclusive as revisões de tratado ou quaisquer outros ajustes complementares. ${ }^{5}$ Nesse aspecto, caso interessante acontece quando um tratado confere poder de revisão não às partes, mas aos órgãos internos da Organização Internacional criada pelo tratado. Trata-se de matéria polêmica, uma vez que, criada por tratado, a Organização Internacional é pessoa internacional distinta das partes contratantes e, em certos casos, dotada de soberania. No entanto, mesmo nesses casos, a experiência tem demonstrado que o Congresso condiciona revisões do tratado à sua aprovação.

Durante o trâmite do tratado no Congresso, este realiza reservas e emendas no texto. Alguns autores criticam isso, pois, em tese, a mudança do texto do tratado seria matéria de competência do Executivo, e não do Legislativo. No entanto, reconhece-se que, na prática, caso o Congresso não pudesse realizar tais reservas e emendas, isso levaria à rejeição de tratados. Aliás, é justamente em função disso que é raro o Congresso rejeitar um tratado. Um dos poucos exemplos conhecidos é a Convenção $n^{\circ} 90$ da Organização Internacional do Trabalho, relativa ao trabalho noturno de menores em indústrias. Nesse caso, o Congresso rejeitou o tratado porque a regra nele contida no tocante aos requisitos etários mínimos para trabalho noturno de menores era menos favorável que a da legislação brasileira.

Caso o tratado seja aprovado, cabe ao presidente do Congresso editar Decreto Legislativo e determinar sua publicação. No entanto, o referendo não transforma o tratado em direito interno, dando-lhe aplicabilidade e eficácia. Aqui cabe uma ressalva. Poder-se-ia dizer simplesmente que o referendo não dá vigência ao tratado, o que seria um equívoco. Vigência o tratado tem desde sua assinatura. O que lhe falta é aplicabilidade e eficácia no direito interno. ${ }^{6}$ Daí a afirmação supracitada.

Publicado o Decreto Legislativo, pode o Presidente realizar a ratificação do tratado, emitindo carta de ratificação a quem de direito. Trata-se, mais uma vez, de faculdade discricionária do presidente. ${ }^{7}$

Muito se discute se as disposições do tratado passam a ter aplicabilidade desde o Decreto Legislativo, desde a ratificação pelo Presidente ou a partir do Decreto Executivo do Presidente da República. Alguns autores, como Paulo de Barros Carvalho, Estevão Horvath e Hamilton Dias de Souza, defendem que é a partir do Decreto Legislativo, uma vez que o Executivo já teria manifestado sua anuência com 
o texto do tratado ao enviá-lo ao Congresso, bastando apenas o referendo deste para lhe dar aplicabilidade e eficácia. No plano ideal, em que apenas ao Executivo caberia fazer reservas e emendas aos tratados, o posicionamento destes autores teria procedência, mas, considerando a prática no trâmite dos tratados no Congresso, é difícil vislumbrar aplicabilidade e eficácia a tratados que podem conter reservas e emendas que não foram ratificadas pelo Executivo.

Tôrres (2001, p. 568) apresenta posicionamento interessante sobre a questão. Afirma o autor que o tratado teria aplicabilidade e eficácia desde a ratificação pelo Presidente, sendo desnecessário o Decreto Executivo para tal. Segundo o autor, caso o tratado só passasse a valer no direito interno a partir do Decreto Executivo, teríamos situação inusitada em que o tratado, após sua ratificação, vigoraria apenas no plano internacional, sem gerar efeitos no plano interno, o que colocaria o Brasil na privilegiada posição de poder exigir a observância do pactuado pelas outras partes contratantes, sem ficar sujeito à obrigação recíproca, atribuindo os respectivos direitos aos destinatários do seu conteúdo ou realizando os deveres ali estabelecidos. Isso tudo porque o tratado teria ficado à mercê de um mero ato administrativo, o Decreto Executivo do Presidente da República.

Outros autores, como João Grandino Rodas e Francisco Rezek, defendem a necessidade do Decreto Executivo do Presidente para que o tratado seja aplicável. Justificam isso alegando que, como o sistema brasileiro evoluiu, por razões de certeza jurídica, no sentido de apenas viabilizar a validade de uma regra cujo conteúdo fosse dado a conhecer previamente aos destinatários desta, não haveria motivo para pretender que uma regra convencional pudesse ser aplicada internamente antes que a publicidade tivesse ocorrido. Segundo Rezek, apesar de a publicidade não ser uma regra constitucional e não estar prevista em local algum, seria o "produto de uma praxe tão antiga quanto a Independência e os primeiros exercícios convencionais do Império" (REZEK, 1984, p. 385).

A despeito do posicionamento dos autores citados, em especial Tôrres, o Supremo Tribunal Federal tem entendimento jurisprudencial consolidado, estabelecendo que é realmente a partir do Decreto Executivo do Presidente da República que os tratados passam a ter validade na ordem interna. ${ }^{8}$

Até a Emenda Constitucional $n^{\circ} 45 / 2004$, muito se discutia também se os $\S \S 1 .^{\circ}$ e 2. ${ }^{\circ}$ do art $5 .^{\circ}$ da Constituição Federal contemplariam uma hipótese de incorporação automática no direito interno para normas definidoras de direitos e garantias fundamentais. Entre os doutrinadores que defendem essa hipótese, podem-se citar Betina Treiger Grupenmacher, Antônio Augusto Cançado Trindade e Alberto Xavier. Aliás, este último autor, em trabalho conjunto com Helena Araújo Lopes Xavier, entende que os tratados em matéria tributária - entre os quais se encontram os acordos de bitributação - também devem ser recepcionados automaticamente no direito interno. Isso porque, segundo os autores, também os tratados que versam sobre 
matéria tributária tendem a salvaguardar os interesses dos contribuintes, mediante a enunciação de garantias a estes. ${ }^{9}$

Em razão dos parágrafos supramencionados do art. 5. ${ }^{\circ}$ da Constituição, há inclusive autores que defendem que o sistema brasileiro teria adotado o sistema monista, que, em conjunto com art. 98 do Código Tributário Nacional, asseguraria prevalência ao direito internacional.

A discussão perdeu seu objeto com a Emenda Constitucional n ${ }^{\circ} 45 / 2004$, que veio introduzir o $\S 3 .^{\circ}$ no art. 5. ${ }^{\circ}$ da Constituição. Segundo a nova redação do artigo, os tratados e convenções internacionais sobre direitos humanos aprovados em cada Casa do Congresso Nacional pelo mesmo processo deliberativo das emendas constitucionais serão equivalentes a estas. O parágrafo citado acabou com a discussão sobre a possível incorporação automática no ordenamento brasileiro de tratados internacionais que versem sobre direitos humanos, uma vez que deixou clara a necessidade de apreciação pelo Congresso Nacional para que possam ser incorporados.

No entanto, a despeito de ter solucionado uma questão, o parágrafo levantou outras indagações. Ponto interessante que se levanta em razão desse parágrafo refere-se à jurisprudência do Supremo Tribunal Federal sobre a admissibilidade de preceito constitucional fora da Constituição. A jurisprudência do Supremo é pacífica no sentido de não admitir preceito constitucional para além do texto formal da Constituição. Entendemos que esse posicionamento do Supremo deverá agora ser revisto. Ora, se o tratado internacional sobre direitos humanos é equivalente à emenda constitucional, tem-se uma matéria constitucional que não está inserida em preceito normativo formalmente constitucional, ao contrário, surge uma matéria constitucional fora do texto constitucional formal. Não obstante, até o presente momento, o Supremo não se posicionou em relação à questão.

Há também autores que defendem que os tratados, quando fundados no âmbito de um acordo de integração, como o Mercosul, teriam recepção automática, por força do disposto no art. $4 .^{\circ}$ da Constituição Federal. No entanto, trata-se de posicionamento minoritário na doutrina, tendo a jurisprudência do Supremo Tribunal Federal inclusive já se posicionado sobre o assunto, decidindo que tais casos não contemplam hipótese de recepção automática no direito interno brasileiro. ${ }^{10}$

Considerando o exposto, e fazendo remissão ao tópico anterior, vemos que a corrente à qual o Brasil mais se aproxima seria a do dualismo moderado. Esse é o posicionamento, por exemplo, de Betina Treiger Grupenmacher. No entanto, a autora ressalta que, em razão das peculiaridades presentes no sistema brasileiro, em especial a ausência de uma disposição constitucional referente à hierarquia dos tratados perante as leis, o nosso sistema representaria um dualismo moderado com temperamentos (GRUPENMACHER, 1999, p. 72).

Atualmente, a situação foi esclarecida pelo posicionamento adotado pelo Supremo Tribunal Federal em dois leading cases: a ADIn $1.480^{11}$ e a CR 8.27912. Em ambas as 
oportunidades, o Supremo se pronunciou de forma uníssona, direta e precisa sobre o tema do monismo e dualismo, acabando com as dúvidas antes existentes. Destaca-se a posição do Supremo na CR n ${ }^{\circ} 8.279$, nas passagens em que classifica o sistema brasileiro como dualismo moderado, com base, entre outros, no RE $\mathrm{n}^{\circ} 71.154 .{ }^{13}$

O RE n 71.154 é outro leading case sobre a matéria. O caso trata de um conflito entre a Lei do Cheque, de 1912, e a Lei Uniforme de Genebra sobre os cheques, de 1931. O Juiz de primeira instância julgou prescrita a ação de cobrança do cheque em virtude de já ter decorrido o prazo prescricional de seis meses previsto no art. 52 da Lei Uniforme de Genebra sobre os cheques. Já o art. 52 da lei brasileira de 1908 sobre letra de câmbio, ao qual o art. 15 da lei de cheque de 1912 remetia, estabelecia prazo prescricional de cinco anos. O Juiz de segunda instância reformou a decisão, alegando que a Convenção de Genebra não teria afetado a lei brasileira sobre o cheque, pois convenções internacionais não seriam diretamente aplicáveis, necessitando de aprovação de uma lei pelo Congresso para tal fim.

No recurso para o Supremo Tribunal Federal, o relator do caso, Ministro Oswaldo Trigueiro, rejeitou a opinião dualista do Tribunal paraense. O Ministro argumentou que o Congresso é quem aprova tratados e leis, seguindo o mesmo procedimento legislativo. Não haveria sentido em exigir lei específica reproduzindo conteúdo do tratado para tal. Por fim, o Ministro afirma também que a Constituição arrola entre as competências do Supremo Tribunal Federal rever decisões que atentem contra leis ou tratados, donde se entende que não haveria necessidade de lei reproduzindo ipsis litteris o conteúdo do tratado.

Dessa forma, por todo o exposto, pode-se dizer As opiniões que defendem a filiação do Brasil à corrente do monismo moderado encontram-se superadas em face do pronunciamento recente do Supremo Tribunal Federal.

\section{Hierarquia de lei e tratado na Constituição}

Uma vez superada a questão referente à sistemática brasileira de incorporação de tratados no ordenamento interno, pode-se passar à etapa seguinte da análise, o exame sobre o patamar hierárquico destes no sistema. Quanto a esse aspecto, deve-se dividir a análise em dois momentos. Em primeiro lugar, deve-se analisar a posição hierárquica dos tratados perante a própria Constituição e, em segundo lugar, a sua posição diante do ordenamento infraconstitucional.

\section{I Conflito entre tratado e Constituição}

A Constituição contempla uma solução expressa quando há conflito entre ela e um tratado. Esse entendimento pode ser depreendido da análise do art. 102, III, $b$, da Constituição Federal, que preceitua o controle de constitucionalidade dos tratados internacionais. 
Apesar de a Constituição prever o controle de constitucionalidade dos tratados, são muito raros os casos em que isso ocorreu. Pode-se citar decisão do Supremo Tribunal Federal, em 1974, que declarou a inconstitucionalidade, em parte, de alguns artigos da Convenção da OIT $\mathrm{n}^{\circ} 110$ referentes às condições de trabalhadores em fazenda. ${ }^{14}$

Dessa forma, o fato de os tratados estarem sujeitos a controle de constitucionalidade, na forma do art. 102, III, b, bastaria para concluirmos que tais instrumentos estão subordinados à Constituição.

Não obstante, conforme referido há pouco, em virtude dos $\S \S 1 .^{\circ}$ e $2 .^{\circ}$ do art. $5 .^{\circ}$ da Constituição, bem como o § 3. ${ }^{\circ}$ inserido com a Emenda Constitucional 45/2004, ainda há divergências quanto a esse posicionamento.

Entre os autores que defendiam o status constitucional dos $\S \S 1 .^{\circ}$ e $2 .^{\circ}$ do art $5 .^{\circ}$ antes da Emenda Constitucional de 2004, podem-se citar Grupenmacher, Antônio Augusto Cançado Trindade, Celso Ribeiro Bastos, Manoel Gonçalves Ferreira Filho e Celso de Albuquerque Mello. Vale também reiterar o já mencionado posicionamento de Xavier, segundo o qual até tratados em matéria tributária cairiam no escopo dos parágrafos.

De qualquer forma, pode-se dizer que a questão foi pacificada no julgamento da ADIn $n^{0} 1.480$ pelo Supremo Tribunal Federal. À ocasião, tratando especificamente da posição hierárquica da Convenção $n^{\circ} 158$ da Organização Internacional do Trabalho perante a Constituição, o Tribunal decidiu de forma praticamente unânime que esta se encontraria em posição de paridade com leis federais, não podendo nunca dispor em sentido contrário à Constituição. O único voto a favor do status constitucional da Convenção foi do Ministro Carlos Velloso; no entanto, ressalta-se que isso se deu em momento anterior à promulgação da Emenda $n^{\circ}$ 45/04.

\subsection{Conflito entre tratado E Legislação interna}

Não há, na Constituição Federal brasileira, dispositivo que verse sobre a hierarquia de normas entre tratado e legislação interna. Nesse sentido, observa-se que a nossa Constituição andou no sentido contrário ao de Constituições de outros países, como Argentina e Paraguai, que asseguram constitucionalmente caráter superior aos tratados perante as leis.

Tôrres (2001, p. 562) tem posicionamento contrário à questão. Alega que:

[...] a maioria dos doutrinadores que a Constituição do Brasil não contém enunciados expressos que disponham sobre o reconhecimento do Direito Internacional e o procedimento de recepção à ordem interna, salvo algumas poucas e esparsas referências às formas procedimentais, encontradas no bojo das normas de repartição de competências, como se vê nos arts. 21, I; 49, I; 84, VIII, da CF. Contrariamente, entendemos que a Constituição Federal disponibiliza sim um conjunto de enunciados, decerto restrito, mas adequado 
para dizermos, sobre a recepção e a posição que devem os tratados ocupar no direito interno.

Em seguida, baseando-se na interpretação dos já mencionados arts. $4 .^{\circ}$ e $5 .^{\circ}, \S 2 .^{\circ}$, da Constituição Federal, bem como o procedimento formal de saída de um tratado, o autor defende que os tratados firmados pela República são mantidos no direito interno subordinados à Constituição e com prevalência de aplicabilidade sobre qualquer lei, complementar ou ordinária; federal, estadual, distrital ou municipal; anterior ou posterior ao seu ingresso na ordem jurídica.

Em que pese o respeito ao posicionamento do autor, há de se reconhecer que a Constituição não oferece uma solução direta e explícita no tocante à hierarquia entre tratados e lei ordinária, e, por mais legítima que seja a solução oferecida, estará sempre sujeita a questionamentos. Nesse sentido, consideramos mais oportuna uma análise sobre alguns dos leading cases a respeito do assunto.

Considerando a interpretação dos tribunais quanto à questão, podem-se identificar dois momentos bastante distintos concernentes ao tratamento da matéria no Brasil, quais sejam o período pré-década de 1970 e o período pós-década de 1970.

\subsection{Período PRÉ-DÉCADA DE I 970}

Nos primeiros tempos da República, a jurisprudência e a doutrina brasileiras postulavam um quase monismo jurídico. Admitiam-se a validade e a aplicabilidade do tratado, mesmo em afronta à Constituição, quando este tivesse sido aprovado e ratificado antes do texto constitucional. Os tratados, superiores às leis, sobrepujavam inclusive a Constituição, em certos casos. Um dos casos que ilustra esse posicionamento é o habeas corpus $\mathrm{n}^{\circ} 2.280,{ }^{15}$ de 1905 , em que se deu prevalência a um tratado de extradição com a Itália, mesmo havendo divergência em face da Constituição de 1891. Nesse sentido, também é citado freqüentemente o Julgamento da Extradição n ${ }^{0} 7,{ }^{16}$ de 1914. À ocasião, aplicou-se tratado celebrado com a Alemanha contra a Lei $n^{\circ} 2.416$, de 1911. A referida lei exigia que documentação de extradição fosse autenticada, com o reconhecimento, pelo representante diplomático brasileiro, e de uma série de outros requisitos. Além disso, todo pedido devia passar pelo Judiciário. Considerando não terem sido atendidas as exigências mencionadas, o Supremo Tribunal Federal rejeitou o pedido.

Entretanto, após a decisão do Supremo, o Ministério da Justiça encaminhou uma comunicação ao Tribunal dizendo que o pedido havia sido equivocado, pois a lei que regulava o processo de extradição era de 1911, enquanto o tratado com a Alemanha era de 1877. Dessa forma, ressaltou que, quando o pedido da Alemanha foi feito, ainda estava em vigor o tratado entre eles (1877), que só seria denunciado em 1913. O tratado entre os dois países não exigia nenhuma das formalidades constantes da Lei $\mathrm{n}^{\circ}$ 2.416/1911. Além disso, o tratado também estipulava que a extradição seria concedida sem pronunciamento do Judiciário. 
Considerando o comunicado do Ministério da Justiça sobre a questão, o Supremo Tribunal Federal reuniu-se novamente e reconheceu sua incompetência para julgar o caso, haja vista as disposições do tratado entre Brasil e Alemanha, de 1877. Assim, o pedido de extradição foi finalmente deferido.

Em outra oportunidade, na Apelação Cível $n^{\circ} 9.587,{ }^{17}$ a Companhia Rádio Internacional do Brasil propôs ação contra a União Federal para obter a restituição de certa importância, acrescida de juros e mora, proveniente de imposto que lhe fora cobrado na importação de radiorreceptores e radiotransmissores dos Estados Unidos. A autora sustentava que a cobrança seria ilegal em virtude de tratado de comércio celebrado entre Brasil e EUA, regularmente integrado ao ordenamento pátrio, segundo o qual não seria possível, nessas operações, cobrar imposto maior que o cobrado no Brasil ou nos EUA, na data da celebração do tratado. ${ }^{18}$ Novamente, o Supremo reconheceu a aplicação das disposições do tratado para o cômputo do tributo devido.

À ocasião, o Supremo Tribunal Federal consolidou também seu posicionamento de que o tratado revogaria as leis que lhe fossem anteriores, mas não poderia, entretanto, ser revogado pelas posteriores, se estas não o fizessem expressamente ou não o denunciassem. A ementa é clara e determina o quanto segue: "O tratado revoga as leis que lhe são anteriores; não pode, entretanto, ser revogado pelas posteriores, se estas não o fizerem expressamente ou se não o denunciarem". 19

Posicionamento igual foi adotado pelo Ministro Orosimbo Nonato na $\mathrm{AC} \mathrm{n}^{\circ}$ 8.332, ${ }^{20}$ de 1944. Segundo o Ministro:

[...] o Estado, vinculado por tratado, não pode citar lei alguma que contrariasse esse tratado [...] Enquanto não fizer a denúncia não pode ser descumprido o tratado e a obrigatoriedade de sua observância, a não ser que use desse meio específico, acarreta a conseqüência de que o Estado continua preso ao tratado.

Muito se discute na doutrina quanto à interpretação adequada de tais leading cases. Alguns sustentam o posicionamento de que esses casos serviriam para demonstrar que, naquele período, o Supremo Tribunal Federal teria consagrado a preponderância dos tratados sobre as leis. Assim, o tratado estaria em um nível hierárquico superior ao das leis e, por isso, não poderia ser revogado por elas.

Já outros sustentam que os referidos casos não colocaram os tratados internacionais em patamar superior ao das leis, tendo estas apenas salientado que, independentemente da relação hierárquica, os tratados seriam leis especiais, com método próprio de revogação, qual seja, a denúncia. Assim, os tratados não poderiam ser revogados por leis porque isso seria uma impropriedade técnica, e não porque seria superior a estas.

De fato, em nenhum dos casos analisados pôde-se encontrar uma transcrição taxativa de ementa ou voto de Ministro, donde se depreenda que os tratados seriam 
superiores às leis. Ao contrário, encontramos posicionamento no sentido de que os tratados seriam leis especiais. Assim, pode-se citar trecho do voto do Ministro Lafayette de Andrada, segundo o qual: "Os tratados constituem leis especiais e por isso não ficam sujeitos às leis gerais de cada país, porque, em regra, visam justamente a exclusão dessas mesmas leis". ${ }^{21}$

A despeito das diferentes interpretações sobre os casos, atendo-se ao núcleo comum das decisões, pode-se afirmar que, no período pré-década de 1970, segundo a interpretação do Supremo Tribunal Federal, os tratados não poderiam ser revogados por leis posteriores, a não ser que estas o fizessem expressamente ou que aqueles fossem denunciados.

\subsubsection{Período PÓS-DÉCADA DE I 970}

Em 1977, com o julgamento do RE $\mathrm{n}^{\circ} 80.004,{ }^{22}$ o Supremo muda seu entendimento. O caso tratou de conflito entre as disposições do Decreto-lei n ${ }^{\circ}$ 427/1969 e a Lei Uniforme de Genebra. Em razão do posicionamento do Supremo sobre as questões ali tratadas, sua decisão é considerada uma das mais importantes em matéria de direito internacional já exarada pela mais alta Corte do País. Segundo Dolinger, todos os internacionalistas brasileiros foram surpreendidos pelo seu teor, que ia de encontro à opinião doutrinária absolutamente majoritária em matéria de conflito entre o direito interno e o internacional e, segundo os críticos, representou uma reviravolta total na posição do Tribunal (DOLINGER, 1996, p. 91)

O caso teve origem com a edição do Decreto-lei n $427 / 1969$, que determinou o registro obrigatório de todas as letras de câmbio e notas promissórias na repartição fiscal competente (repartição fazendária), como requisito de sua validade. O decreto estabelecia que, sem o registro, a ser efetuado nos 15 dias posteriores ao saque do título, este não poderia ser protestado, nem admitido à cobrança judicial, já que seria nulo e inválido. A medida tinha como objetivo propiciar maior controle sobre o mercado financeiro paralelo que existia à época.

A Lei Uniforme de Genebra enumera os requisitos das letras de câmbio no art. 1. ${ }^{\circ}$, e das notas promissórias, no art. 75. O Decreto-lei n 427/1969 acrescentou outro requisito para a validade desses títulos de crédito - o registro junto à repartição fiscal competente. No entanto, isso ia além do que estipulava a Lei Uniforme de Genebra, pelo que significava uma alteração daquele acordo internacional aprovado e ratificado.

Rubens Requião, em um artigo de grande repercussão à época, defendeu que títulos que apresentassem os requisitos da lei uniforme seriam válidos. Segundo ele, países signatários e aderentes se despiram do direito e da faculdade de cominarem a nulidade, pelas suas legislações nacionais, de títulos cambiários que não contivessem o tributo do selo, quando existisse tal exigência (REQUIÃO, 1971, p. 28).

O relator do caso, Ministro Xavier de Albuquerque, adotou entendimento predominante no País de que o Decreto não poderia revogar tratado. Para tal, apoiou-se 
nos doutrinadores brasileiros, especialmente o mencionado artigo de Requião sobre o assunto, bem como a jurisprudência passada do Supremo sobre o assunto.

O Ministro Cunha Peixoto divergiu do relator. Iniciou seu voto de forma radical, afirmando que as Convenções de Genebra não eram lei no Brasil, uma vez que não havia sido promulgada lei interna sobre a matéria, tendo o tratado sido apenas ratificado. Trata-se de posicionamento alinhado com um dualismo extremado, que contrasta com decisões anteriores do Supremo Tribunal Federal. O Ministro citou também os exemplos da Alemanha, França e Itália, que haviam promulgado leis internas sobre a matéria, não se limitando a ratificar o tratado, nem a considerá-lo direito interno nos seus respectivos países. Em seu voto, o Ministro cita uma colocação de Amílcar de Castro, que ilustra bem seu ponto de vista:

parlamento é todo poderoso, mas não pode transformar homem em mulher; da mesma forma, lei estatal é onipotente, mas como o direito internacional rege relação entre Estados, enquanto direito interno relações diversas, não pode transformar direito internacional em direito interno.(CASTRO, 1987, p. 26)

Vale ressaltar também que o Ministro descarta em seu voto a aplicabilidade do art. 98 do Código Tributário Nacional, afirmando que o dispositivo versaria apenas a respeito dos tratadoscontratuais, e não tratadosnormativos. Esse é um tópico importante neste trabalho, objeto de análise detida mais adiante.

O Ministro Cordeiro Guerra discorda do Ministro Cunha Peixoto no tocante à não-incorporação da Convenção de Genebra no ordenamento interno. Nesse sentido, cita o já mencionado $\mathrm{RE}^{\circ}$ 71.154, que, segundo ele, teria pacificado a matéria. De acordo com o magistrado, da mesma forma como um tratado posterior derroga a lei, também a lei posterior derroga o tratado anterior, segundo o princípio lex posterior derrogat lex priori. Por ausência de previsão constitucional expressa, tratado e lei estariam no mesmo patamar no Brasil. Finalmente, na esteira do posicionamento de Cunha Peixoto, o Ministro limita o escopo do art. 98 do Código Tributário Nacional aos acordos contratuais.

O voto do Ministro Leitão de Abreu é considerado o mais importante no julgamento. Ele diverge do Ministro Cunha Peixoto, afirmando que a Lei Uniforme de Genebra estaria integrada ao ordenamento pátrio. Para tal, cita novamente o RE $\mathrm{n}^{\circ}$ 71.154. Após referir-se ao princípio do later in time rule seguido nos Estados Unidos, citando Bernard Schwartz em The powers of government e retornando às lições de Kelsen sobre a querela entre monismo e dualismo em sua Teoria geral do direito e do Estado, o Ministro argumentou que, embora a Constituição estabelecesse a competência do Supremo para decidir a inconstitucionalidade de leis e tratados, daí não se inferia que ambos tivessem o mesmo status. Segundo o Ministro, tanto lei como tratado estariam abaixo da Constituição, o que não significaria que tivessem sido 
equalizados; eles manteriam suas características específicas e diferenciadas. Dessa forma, declarou que não poderia aderir à teoria segundo a qual a lei posterior derroga o tratado anterior, especialmente considerando que um tratado só pode ser revogado pela sua denúncia ou por outro tratado. Assim, segundo sua opinião, não se podia dizer que o Decreto-lei $n^{\circ}$ 427/1969 tivesse revogado as normas da Lei Uniforme de Genebra com que conflitasse (DOLINGER, 1996, p. 92). No entanto, o Ministro reconhece que tribunais são obrigados a aplicar a lei interna do Estado, só estando autorizados a deixar de fazê-lo na presença de permissão constitucional para tal. Como não haveria tal autorização para deixar de aplicar a lei em conflito com o tratado, conseqüentemente os tribunais não teriam outra alternativa se não aplicar a lei, mesmo quando ela conflitasse com o tratado.

O magistrado salienta, no entanto, que isso não significava a revogação do tratado, mas apenas que lei posterior excluiria a aplicabilidade dele, quando houvesse conflito. É algo diferente de revogação, pois, nesse caso, se a lei viesse a ser revogada no futuro, não voltaria a ser aplicável, enquanto, naquela hipótese, se a lei viesse posteriormente a ser revogada, as disposições do tratado que haviam sido afastadas voltariam a ter aplicabilidade. Aliás, vale salientar que isso de fato ocorreu em 1979, e o Supremo Tribunal Federal continuou a aplicar as disposições da Lei Uniforme de Genebra.

A decisão do Supremo Tribunal Federal no RE nº 80.004 foi alvo de muitas críticas na doutrina. José Carlos Magalhães, escrevendo sobre a responsabilidade do Estado na arena internacional, disse que "as decisões dos tribunais são também atos do Estado; elas refletem sobre a ordem internacional e podem vincular a comunidade internacional". O autor acrescentou ainda que o acórdão do caso era fraco, uma vez que as opiniões dos ministros se baseavam em raciocínios diferentes, permanecendo, portanto, a esperança de que o Tribunal eventualmente modificasse seu entendimento (MAGALHÃES, p. 61-66 apud DOLINGER, 1996, p. 93).

Uma das críticas mais ácidas foi formulada por Celso Albuquerque de Mello, que justifica seu posicionamento com base em três argumentos. Em primeiro lugar, cita o art. 98 do Código Tributário Nacional que, segundo ele, atribuiria primazia dos tratados sobre a lei interna. Em segundo lugar, cita os arts. 10, 11 e 12 da Convenção de Havana, que estabeleceriam que um Estado contratante só poderia se abster de aplicar tratado com assentimento dos demais. Os tratados permaneceriam vigentes mesmo após mudança da Constituição da parte contratante, e a parte que se recusasse a aplicar o tratado seria responsabilizada por danos advindos desse ato. Por fim, cita a jurisprudência precedente do Supremo Tribunal Federal, que, segundo o autor, teria consagrado o primado do direito internacional sobre o direito interno (MELLO, [s.d.], p. 86).

Outros autores alegam que a referida decisão seria prejudicial para processos de integração econômica. Baseiam seu entendimento no inciso IX e parágrafo único do 
art. 4. ${ }^{\circ}$ da Constituição Federal, segundo os quais o Brasil buscará a integração econômica com os demais países da América Latina. De acordo com os autores, tais dispositivos demonstram que o constituinte não pretendeu apenas incentivar, mas conduzir em definitivo uma real integração com outros países. A única maneira de fazer isso seria por meio da prevalência dos tratados sobre as leis. Com base nisso é que Hamilton Dias de Souza, por exemplo, defende a hierarquia superior dos tratados perante as leis.

Não obstante, há divergências na doutrina. Dolinger, por exemplo, afirma que a referida decisão não mudou nada (DOLINGER, 1996, p. 91). Ele se posiciona como uma "voz solitária" entre os professores brasileiros a aplaudir a decisão e procura demonstrar que o julgado não só foi sensato, como não destoou das decisões anteriores do Supremo Tribunal Federal. Segundo o autor, não haveria por que invocar o art. 98 do Código Tributário Nacional no caso, uma vez que este teria natureza excepcional, como declarou o Supremo Tribunal Federal. Em segundo lugar, a Convenção de Havana não teria nenhuma influência em matéria legal totalmente interna, e a responsabilidade que esta preceitua em seu art. 12 deve ser entendida como referente apenas a tratados contratuais. Por fim, o autor sustenta que não há contradição entre a jurisprudência anterior do Supremo e a decisão no caso da nota promissória, o que seria demonstrado por decisões posteriores em que os tratados seriam aplicados a despeito de leis posteriores conflitantes (DOLINGER, 1996, p. 94).

Conquanto o posicionamento de Dolinger seja posição minoritária na doutrina, é certo afirmar que, pelo menos em matéria tributária, e especialmente com relação aos acordos de bitributação, não houve grandes mudanças decorrentes do julgamento do $\mathrm{RE} \mathrm{n}^{\circ} 80.004$.

De fato, observa-se que os ministros amparam parte de seus posicionamentos na interpretação do art. 98 do Código Tributário Nacional, bem como na classificação de tratados em normativos e contratuais. Os ministros inclusive fizeram questão de ressaltar que o caso tratava de matéria de direito comercial e que, se a matéria fosse tributária, a solução seria diversa. Dessa forma, observa-se que o tribunal não inovou em matéria tributária, mantendo seu entendimento sobre a prevalência desses tratados sobre a legislação infraconstitucional.

Considerando a importância do art. 98 do Código Tributário Nacional e a divisão entre tratados-norma e tratados-contrato para o Supremo Tribunal Federal. Esses dois pontos serão objeto de análise nos tópicos a seguir.

\section{ARTIGO 98 DO CÓDIGO TRIBUTÁRIO NACIONAL}

$\mathrm{O}$ art. 98 do Código Tributário Nacional prevê a primazia dos tratados sobre a legislação interna, impondo a observância do quanto estabelecido nos tratados e convenções internacionais pela legislação posterior que lhes sobrevenha. 
Pela redação do dispositivo, podem-se realizar duas inferências básicas. Em primeiro lugar, constata-se que os tratados internacionais "revogam" ou modificam legislação tributária interna que lhes preceda. Em segundo lugar, tratados internacionais prevalecem sobre legislação tributária que lhes sobrevenha.

Salienta-se que o artigo contém uma imprecisão terminológica, pois lei interna não é revogada pela norma internacional. A norma interna permanece válida e eficaz dentro do ordenamento interno, somente com sua eficácia paralisada em relação aos atos e fatos conflitantes com a norma internacional.

Nesse sentido, pode-se citar o comentário de Xavier, segundo o qual:

[...] é incorreta a redação deste preceito quando se refere à revogação da lei interna pelos tratados. Com efeito, não se está aqui perante um fenômeno ab-rogativo, já que a lei interna mantém a sua eficácia plena fora dos casos subtraídos à sua aplicação pelo tratado. Trata-se, isso sim, de limitação da eficácia da lei que se torna relativamente inaplicável a certo círculo de situações e pessoas, limitação esta que caracteriza o instituto da derrogação. (XAVIER, 1993, p. 102-103)

Alguns doutrinadores, como Luciano Amaro e Roque Antônio Carrazza, questionam a constitucionalidade do art. 98 do CTN, sob o argumento de que não é atribuição constitucional de lei complementar dispor sobre hierarquia normativa. $\mathrm{Na}$ visão desses autores, somente a Constituição poderia dispor sobre hierarquia de fontes normativas.

Schoueri parece compartilhar dessa opinião. Apesar de não se referir diretamente ao art. 98 do Código Tributário Nacional, examinando o § 2. ${ }^{\circ}$ do Código Tributário alemão, que preceitua a prevalência dos tratados sobre as leis tributárias, desde que se tenham tornado direito interno de aplicação imediata, o autor afirma que se poderia questionar a constitucionalidade do dispositivo, tendo em vista se tratar de mera lei ordinária e, como tal, não poderia tratar de hierarquia de leis.

Há também quem defenda a constitucionalidade do artigo, uma vez que o art. 98 é texto de lei complementar que, por força do art. 146 da CF, tem por função primordial estabelecer normas gerais em matéria tributária, entre as quais encontrar-se-iam também disposições referentes à interpretação, vigência e aplicação da legislação tributária.

É o entendimento, por exemplo, de Sacha Calmon Navarro Coêlho. Segundo o autor:

[...] sempre se entendeu no Brasil que as normas sobre vigência, interpretação e aplicação da legislação tributária são, por excelência, normas gerais de direito tributário, de observância obrigatória pela União, Estados e Municípios. Ao que 
o art. 98 do CTN encartado no capítulo que trata precisamente dessas matérias harmoniza-se com a Constituição à perfeição. (COELHO, [s.d.], p. 186)

Entendimento original é o de José Souto Maior Borges, que afirma não ter pertinência a discussão, uma vez que a norma do art. 98 teria conteúdo meramente declaratório, pois a suspensão da legislação interna seria um dos efeitos próprios do tratado, em razão de sua especialidade.

No tocante à abrangência do art. 98 do Código Tributário Nacional, novamente pode-se encontrar divergência doutrinária. Haroldo Valladão, considerado por alguns um monista radical (DOLINGER, 1996, p.81), defendia a aplicação do art. 98 a todo o sistema jurídico, e não apenas à matéria tributária. Segundo o autor, nem uma nova Constituição poderia afetar tratados em vigor (VALLADÃO, 1980, p. 96, apud DOLINGER, 1996, p.81).

Xavier também parte para uma posição mais radical, defendendo inclusive a superioridade hierárquica dos tratados, independentemente de sua natureza. A razão disso é o argumento já exposto sobre sua interpretação do art. $5 .^{\circ}, \S 2 .^{\circ}$. Assim, a norma não atribuiria hierarquia aos tratados e leis, função exclusiva da Constituição, mas, sim, traria apenas regra acerca de aplicação do tratado em detrimento da lei interna, no caso de conflito entre ambas. No entanto, cabe salientar que se trata de posicionamento exarado antes do advento da Emenda Constitucional $\mathrm{n}^{\circ} 45 / 04$.

Não obstante o posicionamento dos ilustres autores sobre o tema, pode-se dizer que o entendimento do Supremo Tribunal Federal sobre a questão é pacífico no sentido de que o art. 98 do Código Tributário Nacional é aplicável apenas nos casos que envolvam matéria tributária.

\section{TratAdO-NORMA E TRATADO-CONTRATO}

Conforme visto, o Supremo Tribunal Federal atribui grande importância à divisão entre tratados-norma e tratados-contrato. Segundo o entendimento reiterado do Tribunal, apenas os tratados-norma poderiam ser contrariados por lei interna posterior. Os tratados, em matéria tributária, prevalecem sobre a legislação interna que lhes sobrevenha.

Tratados normativos são aqueles que veiculam normas gerais e abstratas, em que as vontades dirigem-se a uma finalidade comum a ser alcançada pela conduta idêntica de todas as partes. Um exemplo dessa espécie seria um tratado sobre proscrição de armas nucleares.

Rodrigo Maitto (2006, p. 75-76) se refere aos tratados normativos como tratadoslei. Segundo o autor, estes têm por finalidade o estabelecimento de normas jurídicas propriamente ditas, sem que haja uma relação sinalagmática previamente constituída. 
Ao contrário dos tratadosnormativos, os tratados-contrato possuem normas individuais e concretas, pelas quais as partes assumem direitos e deveres recíprocos. Segundo Maitto (2006, p. 75-76), os tratados-contrato impõem aos países signatários o dever de agir de um modo específico em situações determinadas, regulando interesses recíprocos mediante concessões mútuas. Nesse sentido, talvez o principal exemplo de um tratado-contrato sejam os acordos de bitributação.

É importante não confundir tratado-contrato com contrato administrativo internacional (state contracts), regido pelo direito nacional e celebrado pelo Estado com particulares fixando normas individuais e concretas, por meio das quais assumem as partes direitos e deveres recíprocos (BAHIA, 2000, p. 4).

Accioly distinguiu os tratados-contrato em executados e executórios. Os primeiros são aqueles que devem ser de logo executados e, quando assim ocorre, dispõem sobre a matéria permanentemente, de uma vez por todas. Um possível exemplo seriam os tratados de fronteiras. Já os tratados executórios são aqueles que prevêem atos que devem ser executados regularmente, todas as vezes em que se apresentem as condições suficientes (ACCIOLY, 1970, p. 139, apud MAITTO, 2006, p. 76).

No entanto, a despeito do tratamento dispensado à matéria, Maitto acentua que, em virtude da precariedade dos argumentos em prol da distinção entre tratadosnormativos e tratados-contrato, esta classificação estaria em declínio (MAITTO, 2006, p. 76). Nesse mesmo sentido, Francisco Rezek afirma que "a distinção entre tratados contratuais e tratados normativos vem padecendo de uma incessante perda de prestígio” (REZEK, 1995, p. 29).

Entre os defensores da diferenciação, pode-se citar Alfred Verdross, discípulo de Kelsen, e Dolinger. Além destes, Schoueri (1995) traz o posicionamento salutar de Klaus Vogel sobre a questão. O autor concorda com a classificação dos tratados de bitributação como tratados-contrato, na medida em que tais instrumentos contemplam concessões mútuas por parte dos países signatários. Entretanto, faz uma ressalva no sentido de que, como os direitos e obrigações firmados pelos Estados têm implicações diretas para os contribuintes residentes em seus territórios, de modo que as autoridades fiscais e os tribunais acabam aplicando as disposições convencionais do mesmo modo que as leis internas, o caráter de reciprocidade desses tratados acaba perdendo relevância, ficando mais próximos, em termos de caracterização, dos tratados-lei.

Entre os críticos da diferenciação, podem-se citar Kelsen, Mello e Tôrres. ${ }^{23}$ Xavier também é contra a diferenciação, alegando que esta só tem utilidade classificatória, mas não pode influenciar a interpretação dos tratados. Nesse sentido, reitera seu já citado posicionamento de que o Brasil adotou o sistema monista e que os tratados têm prevalência sobre as leis, qualquer que seja seu tipo, normativo ou contratual.

Assim, observa-se que há fortes críticas à classificação dos tratados em normativos e contratuais. De fato, parece-nos que a relativa importância que essa classificação 
ainda detém repousa no entendimento jurisprudencial brasileiro, segundo o qual haveria supremacia dos tratados internacionais em relação à ordem jurídica interna, no caso de tratados-contrato, e pela sua inferioridade hierárquica, no caso de tratadosnormativos. Além dessa circunstância, não é possível encontrar nenhuma outra utilidade prática para a classificação.

\section{CONSIDERAÇÕes Finais}

Pelo exposto, pode-se observar que o Supremo Tribunal Federal entende que os tratados em matéria tributária, especialmente os acordos de bitributação, seriam tratados-contrato, o que justificaria a aplicação de um regime específico de solução de antinomias segundo o qual as normas posteriores não poderiam revogar tais tratados.

Procurando interpretar o critério adotado pelo Supremo Tribunal Federal, autores oferecem diferentes posições sobre o assunto. Grupenmacher, por exemplo, defende que a prevalência dos tratados nesses casos se daria em razão da especialidade deles. Segundo a autora:

[...] em matéria tributária, especialmente, é possível afirmar-se a prevalência dos tratados sobre dispositivo de lei interna após a sua aprovação por decreto legislativo, pelo critério da especialidade, pois os tratados são normas especiais, ao passo que a lei interna tem a nota da generalidade. (GRUPENMACHER, 1999, p. 107)

Nesse aspecto, cabe reiterar o posicionamento do Ministro Lafayette de Andrada, em voto proferido nos Embargos à Apelação Cível n 9.583, de que os tratados constituem leis especiais e, por isso, não ficam sujeitos às leis gerais de cada país, porque, em regra, visam justamente à exclusão dessas mesmas leis.

Vogel se refere aos acordos de bitributação como uma máscara que se coloca sobre direito interno, tapando determinadas partes deste. Nessa máscara há buracos, que correspondem aos casos em que o acordo permite o livre exercício da pretensão tributária do Estado. Assim, os dispositivos que continuarem visíveis, por meio de buracos contidos na máscara, são aplicáveis, enquanto os demais não. O autor também esclarece que há possibilidade de existirem buracos na máscara, mas não haver nenhum conteúdo visível. Trata-se dos casos em que o Estado não legislou sobre aquele tributo (VOGEL, 1996, p. 121, apud SCHOUERI, 2003, p. 35).

Tratando da explicação proposta por Vogel, Schoueri (2003, p. 35) afirma que se trataria de uma figura feliz, porque, entre outras razões, mostraria que o tratado não revoga lei interna, apenas prevalece, ou seja, afasta aplicabilidade. A lei interna continua válida, mas tem sua aplicação contida. Trata-se de uma autolimitação da pretensão tributária do Estado, não podendo mais este fazer incidir sua regra de incidência sobre 
as situações comprometidas internacionalmente. Retoma-se assim o conceito de autolimitação da soberania, tratado no início deste artigo.

Conquanto o mecanismo proposto por Vogel seja uma ferramenta muito interessante para explicar a relação entre os tratados internacionais em matéria tributária, observa-se que este não deixa de ser um critério de lex specialis, segundo o qual a lei específica prevaleceria sobre a lei geral. Nesse sentido, é um dos critérios clássicos de solução de antinomias.

Assim, mesmo sendo uma ferramenta útil, acreditamos ser necessário acrescentar outro aspecto a essa explicação, justamente o último ponto levantado por Schoueri ao enaltecer a figura criada por Vogel, qual seja, a autolimitação da pretensão tributária do Estado.

Com efeito, após essa exposição a respeito das fontes do direito internacional e do relacionamento entre os tratados e o direito interno, acreditamos ser necessário fazer uma remissão ao tópico inicial deste trabalho, que tratou justamente da soberania. À ocasião, observou-se que, em face de um contexto internacional atual que impõe cooperação cada vez maior entre países, é necessário que os Estados limitem parte de sua soberania.

Essa autolimitação é reflexo imediato de uma solidariedade de interesses decorrente de um senso comum quanto aos efeitos perversos da bitributação internacional. E é justamente nesse sentido que se observa que não há nenhuma afronta à soberania, mas, antes, a própria preservação desta, uma vez que o Estado, ao autolimitar-se, determina sua vontade por ele próprio, permanecendo soberano.

Esse também parece ser o posicionamento de Schoueri. Tratando da questão das isenções heterônomas decorrentes de tratados internacionais, o autor apresenta um interessante raciocínio, que corresponde à idéia que pretende-se demonstrar. Segundo o autor:

[...] não há que se cogitar da proibição à isenção heterônoma, pois não estamos diante de isenção. Poder de isentar anda junto com o poder de tributar, ou seja, aquele que pode tributar pode isentar. Quando Brasil celebra um acordo em que diz: não vou tributar, não vou discriminar os produtos da Argentina, o que eu tenho é uma renúncia ao poder de tributar, que é momento anterior à própria existência do poder de tributar. Ou seja, do ponto de vista lógico, antes mesmo de um Estado poder tributar um automóvel ele teve esse poder cortado por uma renúncia que o Estado brasileiro fez àquele poder. Insisto nisso: é próprio do Direito Internacional admitir que o Estado renuncie a parte de sua soberania numa relação em que outro Estado também está renunciando. Se não, não haveria Direito Internacional. Eu renuncio porque outros renunciaram. Claro, posso a qualquer momento retomar minha soberania denunciando o tratado 
e dizendo, volto a exercer o poder pleno. Mas enquanto não denunciar esse tratado, renunciei ao exercício desse poder. (SCHOUERI, 1999, p. 68-69)

Embora o autor esteja tratando de isenções heterônomas, assunto que não foi objeto de análise específica aqui, acreditamos ser possível transportar sua linha de raciocínio ao tema deste trabalho. Assim, os tratados internacionais em matéria tributária, em especial os acordos de bitributação, prevalecem sobre o ordenamento interno, não porque seriam uma lei especial, mas, antes, porque o próprio Estado autolimitou sua soberania no tocante à imposição tributária, naqueles casos específicos sobre os quais o tratado versar. Dentro dessa capacidade de autolimitar a imposição tributária, obviamente inclui-se a renúncia ao poder de tributar uma determinada situação, caso em que pode surgir a isenção heterônoma.

Por fim, cabe ressaltar que essa linha de interpretação também não se afasta do princípio do pacta sunt servanda. Se é certo que soberania é princípio universalmente aceito no direito internacional público, também é certo que deve ser respeitado o princípio do pacta sunt servanda. Assim, se o Estado resolveu se comprometer, ou seja, se o Estado decidiu autolimitar sua soberania, então, deve cumprir com as obrigações assumidas. E, conforme visto, a maneira própria de escusar-se destas obrigações é pela denúncia do tratado.

: ARTIGO APROVADO (04/01/2008) : RECEBIDO EM 12/09/2007

\section{NOTAS}

1 No tocante à Convenção de Viena sobre Direito dos Tratados, vale mencionar que este tratado ainda não foi ratificado pelo Brasil. De fato, o texto da Convenção foi encaminhado ao Congresso em 1992. Este foi aprovado na Comissão de Relações Exteriores da Câmara dos Deputados e transformado no projeto de Decreto Legislativo 214/1992. Posteriormente, o texto foi aprovado na Comissão de Constituição, Justiça e Redação da Câmara e encontra-se pronto para a ordem do dia desde 28.10.1995. Não obstante, pela sua importância no direito internacional público, ela é invocada em larga medida, praticamente como se já tivesse sido ratificada. Pode-se dizer que, pela sua importância, as disposições da Convenção transcenderam e já se tornaram verdadeiros costumes internacionais. Cabe mencionar inclusive que referências à Convenção já constam de decretos presidenciais, tais como o Decreto 176/91.

2 Art. $1 .^{\circ}, a$.

3 Diz o mestre da escola de Viena: "Segundo o direito internacional o governo legítimo de um Estado é o governo efetivo e independente. Isto significa que, de acordo com o direito internacional, uma autoridade estabelecida de fato é o governo legítimo, sendo válida a ordem jurídica coercitiva estabelecida por este governo. [...] Assim, as normas 
fundamentais dos diversos ordenamentos jurídicos nacionais são baseadas em uma norma geral do ordenamento jurídico internacional. [...] A norma fundamental do ordenamento jurídico internacional é, também, a razão última da validade dos ordenamentos jurídicos nacionais” (KELSEN, 1966. p. 561-562).

4 “[...] o dualismo dividir-se-ia em radical - no qual haveria necessidade de edição de uma lei distinta para a incorporação do tratado à ordem jurídica nacional - e em moderado - no qual a incorporação prescindiria de lei, embora possuísse iter procedimental complexo, com aprovação congressual e promulgação executiva; o monismo dividir-se-ia também em radical e moderado. O radical pregaria a primazia do tratado sobre a ordem jurídica interna, e o moderado procederia à equiparação hierárquica do tratado à lei ordinária, subordinando-o portanto à Constituição e à aplicação do critério cronológico em caso de conflito. [...]” (ARAÚJO; ANDREIUOLLO, 1999. p. 87-99).

5 O Congresso Nacional, com a edição do Decreto Legislativo 165, de 21.06.1991, firmou o entendimento pela interpretação literal do art. 49, I, da Constituição Federal: "São sujeitos à aprovação do Congresso Nacional quaisquer atos que possam resultar em revisão do Acordo, bem como quaisquer ajustes complementares que, nos termos do art. 49, I, da Constituição Federal, acarretem encargos ou compromissos gravosos ao patrimônio nacional”.

6 “Concluído o tratado, as suas normas entram em vigor. Desde então ele adquire plena validade. A sua existência jurídica preexiste, portanto, ao ato de ratificação pelo Congresso Nacional. Não é simplesmente referendar o inexistente. Dizê-lo válido significa afirmar que o tratado desde logo adquire força obrigatória, i.e., vinculante para as partes nele envolvidas, porque elas não mais poderão unilateralmente liberar-se do vínculo respectivo. Nesse sentido, a recusa do referendo pelo Congresso somente afeta a aplicabilidade do tratado na ordem interna. Não sua validade" (BANDEIRA DE MELLO, Celso, 1997, p. 167.)

7 Há casos de convenções aprovadas pelo Congresso Nacional e não ratificadas pelo Presidente da República, tais como as relativas ao Mar Territorial e à Zona Contígua, sobre o Alto-Mar, sobre Pesca e Conservação dos Recursos Vivos do Alto-Mar e sobre a Plataforma Continental, concluídas em Genebra em 1958.

8 ADIN 1.480-3/DF, rel. Min. Celso de Mello, em 04.09.1997.

9 Segundo os autores: “Ora, a matéria tributária situa-se precisamente no cerne dos direitos e garantias constitucionais, pois não só a própria Constituição assim o considera (art. 150, caput), como atinge de pleno direitos e garantias, como a propriedade privada, a liberdade de comércio e a proibição do confisco" (XAVIER; XAVIER, [s.d.], p. 40).

10 AR 8.279-4, rel. Min. Celso de Mello, em 17.06.1998.

11 ADIN 1.480-3/DF, rel. Min. Celso de Mello, em 04.09.1997.

12 AR 8.279-4, rel. Min. Celso de Mello, em 17.06.1998.

13 RE 71.154, rel. Min. Oswaldo Trigueiro, em 04.08.1971.

14 No final, o Brasil denunciou a Convenção.

15 RHC 2.280/DF, rel. Min. Lúcio de Mendonça, em 14.06.1905.

16 PE 7, rel. Min. Canuto Saraiva, em 07.01.1914.

17 Apelação Cível 9.587, rel. Min. Antônio Carlos Lafayette de Andrada, em 21.08.1951.

18 Apelação Cível 9.587, rel. Min. Antônio Carlos Lafayette de Andrada, em 21.08.1951.

19 Grifos da transcrição.

20 Apelação Cível 8.332, em 07.07.1944.

21 Grifos da transcrição. 
22 Recurso Extraordinário 80.004-SE, rel. Min. Xavier de Albuquerque, em 1.․06.1977.

23 "Quero deixar registrado a minha mais profunda indiferença à corrente e tola distinção entre 'tratadosnormativos' e 'tratados-contratos' [...]” (TÔRRES, 2001, p. 570).

\section{REFERÊNCIAS BIBLIOGRÁFICAS}

XII Congresso Brasileiro de Direito Tributário, Mesa de Debates “C”- Mercosul. Revista de Direito Tributário, São Paulo: Malheiros, n. 75, 1999.

ACCIOLY, Hildebrando. Manual de direito internacional público. Rio de Janeiro: Ministério das Relações Exteriores, 1956.

ARAÚJO, Nádia de; ANDREIUOLLO, Inês da Matta. A internacionalização dos tratados no Brasil e os direitos humanos. Os direitos humanos e o direito internacional. Rio de Janeiro: Renovar, 1999.

BAHIA, Saulo José Casali. Tratados internacionais no direito brasileiro. Rio de Janeiro: Forense, 2000.

BANDEIRA DE MELLO, Celso Antônio. Isenções em Tratados Internacionais de Impostos dos Estados-Membros e Municípios. Direito tributário: estudos em homenagem a Geraldo Ataliba. São Paulo: Malheiros, 1997.

CASTRO, Amílcar de. Direito Internacional Privado. Rio de Janeiro: Forense, 1987.

CO LHO, Sacha Calmon Navarro. Tratados internacionais em matéria tributária perante a Constituição Federal de 1988. Revista de Direito Tributário, São Paulo: Malheiros, n. 59.

DOLINGER, Jacob. As soluções da Suprema Corte brasileira para os conflitos entre o direito interno e o direito internacional: um exercício de ecletismo. Revista Forense, Rio de Janeiro: Forense, n. 334, abr.-jun. 1996.

GRUPENMACHER, Betina Treiger. Tratados internacionais em matéria tributária e ordem interna. São Paulo:

Dialética, 1999.

KELSEN, Hans. Principles of international law. Ed. Robert W Tucker. 2. ed. 1966.

MAITTO, Rodrigo. Aplicação de tratados internacionais contra a bitributação - qualificação de partnership joint ventures. Série Doutrina Tributária, São Paulo: Quartier Latin, v. 1, 2006.

MELLO, Celso D. de Albuquerque. Curso de direito internacional público. v. 1, 2000.

REQUIÃO, Rubens. Cambial: invalidade da lei que exige seu registro. Revista de Direito Mercantil, Industrial,

Econômico e Financeiro, v. 1, 1971.

REZEK, José Francisco. Direito dos tratados. Rio de Janeiro: Forense, 1984.

. Direito internacional público: curso elementar. São Paulo: Saraiva, 1995.

SCHOUERI, Luís Eduardo. Planejamento fiscal através de acordos de bitributação: treaty shopping. São Paulo: RT, 1995.

—. Tratados e convenções internacionais sobre tributação. Direito Tributário Atual, São Paulo: Dialética, n. 17, 2003.

SOARES, Guido Fernando Silva. Curso de direito internacional público. São Paulo: Atlas, 2002. v. 1.

TÔRRES, Heleno. Pluritibutação internacional sobre as rendas de empresas. 2. ed. São Paulo: RT, 2001.

XAVIER, Alberto. Direito tributário internacional do Brasil. 2. ed. Rio de Janeiro: Forense, 1993.

; XAVIER, Helena de Araújo Lopes. Tratados: superioridade hierárquica em relação à lei face à

Constituição Federal. Revista de Direito Tributário, São Paulo: Malheiros, n. 66.

\section{Gustavo Mathias Alves Pinto}

Rua Eng. Edgar Egídio de Souza, n. 36, apto 81

Higienópolis - 01233-020 São Paulo, Brasil

gumathiaslagmail.com
Doutorando EM DIREITO PELA USP, BRASIL Mestre em Direito pela Harvard Law School, eUA 